\title{
Enzymatic Production of Ecodiesel by Using a Commercial Lipase CALB, Immobilized by Physical Adsorption on Mesoporous Organosilica Materials
}

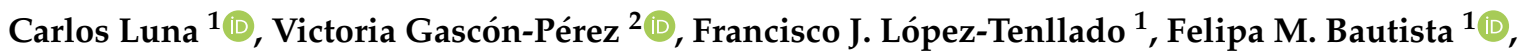 \\ Cristóbal Verdugo-Escamilla ${ }^{3}{ }^{(0)}$, Laura Aguado-Deblas ${ }^{1}{ }^{1}$, Juan Calero ${ }^{1}$, Antonio A. Romero ${ }^{1}\left(\mathbb{D}\right.$, Diego Luna ${ }^{1, *(\mathbb{D})}$ \\ and Rafael Estévez ${ }^{1}$ (D)
}

check for updates

Citation: Luna, C.; Gascón-Pérez, V.; López-Tenllado, F.J.; Bautista, F.M.; Verdugo-Escamilla, C.; Aguado-Deblas, L.; Calero, J.; Romero, A.A.; Luna, D.; Estévez, R. Enzymatic Production of Ecodiesel by Using a Commercial Lipase CALB, Immobilized by Physical Adsorption on Mesoporous Organosilica Materials. Catalysts 2021, 11, 1350. https://doi.org/10.3390/catal11111350

Academic Editors: Aniello Costantini and Valeria Califano

Received: 5 October 2021

Accepted: 8 November 2021

Published: 9 November 2021

Publisher's Note: MDPI stays neutra with regard to jurisdictional claims in published maps and institutional affiliations.

Copyright: (C) 2021 by the authors. Licensee MDPI, Basel, Switzerland This article is an open access article distributed under the terms and conditions of the Creative Commons Attribution (CC BY) license (https:// creativecommons.org/licenses/by/ $4.0 /)$
1 Departamento de Química Orgánica, Universidad de Córdoba, Campus de Rabanales, Ed. Marie Curie, 14014 Córdoba, Spain; qo2luduc@uco.es (C.L.); b52lotef@uco.es (F.J.L.-T.); qo1baruf@uco.es (F.M.B.); aguadolaura8@gmail.com (L.A.-D.); p72camaj@gmail.com (J.C.); qo1rorea@uco.es (A.A.R.); q72estor@uco.es (R.E.)

2 Department of Chemical Sciences, Bernal Institute, University of Limerick, V94 T9PX Limerick, Ireland; Victoria.GasconPerez@ul.ie

3 Laboratorio de Estudios Cristalográficos, Spanish National Research Council (CSIC), Andalusian Institute of Earth Sciences (IACT), Universidad de Granada, Av. De las Palmeras 4, 18100 Granada, Spain; cristobal.verdugo@csic.es

* Correspondence: diego.luna@uco.es; Tel.: +34-957-212-065

Abstract: The synthesis of two biocatalysts based on a commercial Candida antarctica lipase B, CALB enzyme (E), physically immobilized on two silica supports, was carried out. The first support was a periodic mesoporous organosilica (PMO) and the second one was a commercial silica modified with octyl groups (octyl-MS3030). The maximum enzyme load was $122 \mathrm{mg}$ enzyme/g support on PMO and $288 \mathrm{mg}$ enzyme/g support on octyl-MS3030. In addition, the biocatalytic efficiency was corroborated by two reaction tests based on the hydrolysis of p-nitrophenylacetate (p-NPA) and tributyrin (TB). The transesterification of sunflower oil with ethanol was carried out over the biocatalysts synthesized at the following reaction conditions: $6 \mathrm{~mL}$ sunflower oil, $1.75 \mathrm{~mL} \mathrm{EtOH}$, $30{ }^{\circ} \mathrm{C}, 25 \mu \mathrm{L} \mathrm{NaOH} 10 \mathrm{~N}$ and $300 \mathrm{rpm}$, attaining conversion values over $80 \%$ after $3 \mathrm{~h}$ of reaction time. According to the results obtained, we can confirm that these biocatalytic systems are viable candidates to develop, optimize and improve a new methodology to achieve the integration of glycerol in different monoacylglycerol molecules together with fatty acid ethyl esters (FAEE) molecules to obtain Ecodiesel.

Keywords: biofuel; ecodiesel; biodiesel; commercial CALB lipase; ordered mesoporous materials (PMO); amorphous siliceous material MS3030

\section{Introduction}

The technology integrated into current transportation vehicles is suffering a radical change. In this sense, several strategies are gaining a lot of attention, such as electric energy, batteries of different technologies or vehicles based on hydrogen fuel cells. However, it seems highly probable that the use of liquid fuels in internal combustion engines will continue as one of the best solution in a number of specific transportation sectors, i.e., aviation, maritime shipping or heavy vehicles, where the incorporation of new engines is still a challenge [1,2]. Besides, the urgent need for reducing anthropogenic gases implies that this energy transition must consider the engines installed in actual vehicles [3]. In this respect, to fulfill the deadline established in the fuel decarbonization strategy and considering the advantages of using the currently in-use vehicles, the development of biofuels from renewable raw materials is mandatory [4]. In addition, biofuels can be easily integrated into the logistic transportation systems [5]. 
Today, biodiesel is the principal renewable alternative for diesel fuel substitution. As is well-known, biodiesel is obtained from vegetable oils or animal fats, by the transesterification reaction of triglycerides with methanol, obtaining the fatty acids methyl esters (FAME) blend. However, this reaction presents, on an industrial scale, several problems associated with the glycerol generated during the process (10 wt.\% of the total biodiesel produced). This glycerol must be completely removed, together with soap and methanol excess, by repeated washing with water, increasing the costs of the process because of the high amount of water that must be employed [5,6].

To solve these drawbacks, increase the yield of the process and reduce the production costs, the synthesis of biofuels that integrates glycerol as monoglycerides (MG) have been extensively studied [6,7]. Among these biofuels, Ecodiesel ${ }^{\circledR}$ was obtained by enzymatic selective transesterification of one mole of triglyceride (TG) with ethanol; producing two moles of ethyl esters (FAEE) and one mole of monoglyceride (MG), Figure 1. Thus, the atomic performance of the process increased practically to $100 \%$, avoiding the generation of waste glycerol as well.<smiles>[R]C(=O)CC(COC(=O)F)COC(=O)F</smiles>

Triglyceride<smiles>CCO</smiles>

Ethanol

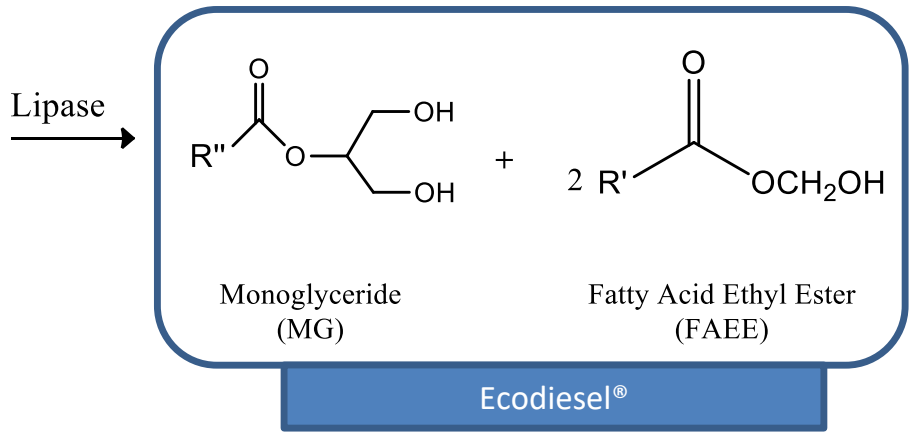

Figure 1. Selective transesterification of a triglyceride molecule through the application of enzymatic catalysis to produce Ecodiesel ${ }^{\circledR}$.

This procedure takes advantage of the 1,3-selective nature of lipases, which stop the reaction in the second alcoholysis step. Thus, several advantages can be obtained, e.g., the generation of glycerol is avoided, the reaction conditions are much milder than with the conventional alkaline process to obtain biodiesel and the generation of impurities (acid or alkaline) is greatly reduced. Another specific feature of the enzymatic process is that ethanol is employed instead of methanol. Several researches initially described the use of pig pancreatic lipase (PPL), in free [8] and immobilized form $[9,10]$ in this transesterification selective process. However, the high price of PPL lipases, even immobilized, represent an important handicap to scale-up the process. Therefore, a high number of low-cost lipases have also been evaluated in both, free-form and/or immobilized on different supports [11-20]. Nevertheless, the economic cost of the enzymatic process continues being the main drawback to achieve economic feasibility at the highest production level.

To further reduce the economic cost of Ecodiesel production, this research studied the production of Ecodiesel on a biocatalytic system obtained by the immobilization of a lipozyme CALB lipase on two tailor-made silica supports. The first one is a periodic mesoporous organosilica, whereas the other is an amorphous silica MS-3030 functionalized with octyl groups (octyl-MS3030). The influence of the hydrophobic nature of both supports along with the porous topology was evaluated. Desorption of the enzyme could be prevented by confinement in the pore channel and by chemical affinity of the hydrophobic surface of the silica. In addition, these silica-type materials have an additional stabilizing effect on enzyme molecules against organic solvents. In this work, sunflower oil has been selected for the evaluation of the enzymatic process, although the final objective is its application in the production of second-generation biofuels to avoid ethical conflicts, due to the foreseeable competition in the uses of edible oils as biofuels. Besides, recycled waste cooking oils are more suitable for enzymatic transesterification because they include a 
large amount of free fatty acids [21]. The application of sunflower oil in this research is exclusively determined by its greater reproducibility, in comparison to the reproducibility that would be achieved using recycled used oils.

\section{Results and Discussion}

2.1. Immobilization of Candida Antarctica Lipase B (CALB) on Periodic Mesoporous Organosilica Materials (E-PMO) and on Octyl-MS3030 (E-Octyl-MS3030)

As has been previously reported, lipases exhibit a strongly hydrophobic domain on its surface, being able to be adsorbed on supports with hydrophobic surfaces and walls [22-24]. Table 1 shows the values of the enzymatic load and the corresponding nonspecific catalytic activities of the biocatalytic systems obtained by the physical adsorption of the lipase CALB on both mesoporous organosilica materials.

Table 1. Results obtained in the enzymatic activity in the hydrolysis of p-nitrophenylacetate (pNPA) as well as in the hydrolysis of tributyrin (TB), thus obtaining the enzyme load of the investigated biocatalysts.

\begin{tabular}{|c|c|c|c|c|c|c|c|}
\hline Biocatalyst & Time (h) & $\begin{array}{l}\text { Max. Load } \\
\left(_{(\mathrm{mg} / \mathrm{g})^{a}}\right.\end{array}$ & $\begin{array}{c}\text { Enzyme } \\
\text { Immob (\%) }\end{array}$ & $\begin{array}{l}\text { Biocat. Act. } \\
\left(U_{\text {pNPA }} / g\right)^{c}\end{array}$ & $\begin{array}{c}\text { Cat. Eff. } \\
\left(\mathrm{U}_{\mathrm{pNPA}} / \mathrm{mg}\right)^{\mathrm{d}}\end{array}$ & $\begin{array}{l}\text { Biocat. Act. } \\
\left(\mathrm{U}_{\mathrm{TB}} / \mathrm{g}\right) \mathrm{e}^{\mathrm{e}}\end{array}$ & $\begin{array}{c}\text { Cat. Eff. } \\
\left(\mathrm{U}_{\mathrm{TB}} / \mathrm{mg}\right)^{\mathrm{f}}\end{array}$ \\
\hline E-PMO & 5 & 122 & 31 & $322 \pm 14$ & 2.6 & $5563 \pm 138$ & 45.6 \\
\hline E-PMO & 3.5 & 100 & 25 & $332 \pm 19$ & 3.3 & $5366 \pm 222$ & 53.6 \\
\hline E-Octyl-MS3030 & 5 & 288 & 72 & $358 \pm 10$ & 1.2 & $10336 \pm 287$ & 35.9 \\
\hline E-Octyl-MS3030 & 3.5 & 236 & 60 & $468 \pm 10$ & 2.0 & $7293 \pm 328$ & 30.9 \\
\hline
\end{tabular}

${ }^{a}$ Maximum enzymatic loading, expressed in milligrams of lipase per gram of support. ${ }^{b}$ Percentage of immobilized enzyme in the solid calculated from the amount of enzyme in the suspension. ${ }^{c}$ Biocatalyst activity expressed in $U_{\text {pNPA }}$ per gram of support. ${ }^{d}$ Catalytic efficiency expressed in $\mathrm{U}_{\mathrm{pNPA}}$ per $\mathrm{mg}$ of lipase. ${ }^{\mathrm{e}}$ Biocatalyst activity expressed in $\mathrm{U}_{\mathrm{TB}}$ per gram of support. ${ }^{\mathrm{f}}$ Catalytic efficiency expressed in $\mathrm{U}_{\mathrm{TB}}$ per $\mathrm{mg}$ of lipase.

A longer immobilization time leads to a higher enzyme binding. Times over $5 \mathrm{~h}$ did not promote a further immobilization. Thus, the loading capacity of PMO for lipase immobilization was $122 \mathrm{mg}$ of lipase per gram of PMO, which was clearly inferior to that exhibited by the octyl-MS3030, around $288 \mathrm{mg}$ lipase per gram of support. This fact could be attributed to the relatively small pore size of the PMO (Table S1 in Supplementary Materials), which would prevent multilayer adsorption of the enzyme. In contrast, lipase loadings up to $288 \mathrm{mg}$ per gram of support were achieved on octyl-MS3030 due to its larger pore size. The higher lipase loadings on octyl-MS3030 promote its higher catalytic activity in both reactions, pNPA and TB. However, the catalytic efficiency values obtained over this E-octyl-MS3030 was lower than that exhibited by E-PMO. This fact could be ascribed to the stronger interaction between the enzyme and the octyl groups of the support, in contrast with the mild interactions of enzyme with the ethylene groups in the wall of E-PMO. These mild interactions allow the catalyst to preserve the high catalytic activity. Nevertheless, the possibility to obtain a protein corona on the surface of the silica nanoparticles cannot be ruled out [25-27].

\subsection{Transesterification of Sunflower Oil with Ethanol to Produce Ecodiesel}

Biocatalysts previously synthesized (E-PMO and E-octyl-MS3030) were tested on the transesterification reaction of sunflower oil with ethanol to produce Ecodiesel and the results are shown in Figure 2. In addition, blank experiments were performed with the supports without immobilized enzyme and did not promote the Ecodiesel production, attaining very similar results as a blank reaction. 


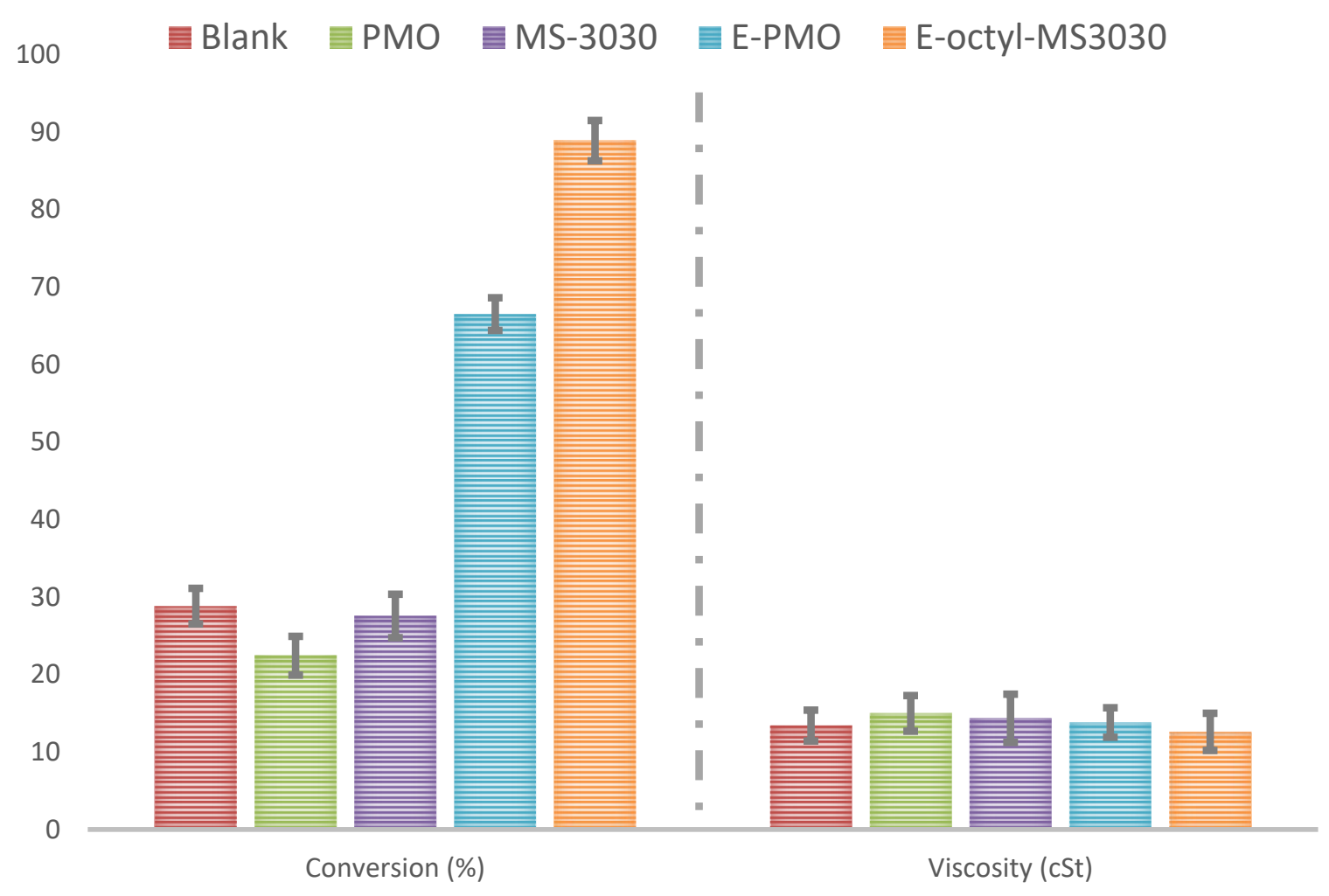

Figure 2. Conversion and viscosity values obtained in the transesterification of sunflower oil with ethanol. Reaction conditions: $6 \mathrm{~mL}$ sunflower oil, $1.75 \mathrm{~mL} \mathrm{EtOH}, 30{ }^{\circ} \mathrm{C}, 25 \mu \mathrm{L} \mathrm{NaOH} 10 \mathrm{~N}, 300 \mathrm{rpm}$ and $10 \mathrm{~h}$ of reaction time. Biocatalyst weight: $0.1 \mathrm{~g}$ of E-PMO or $0.05 \mathrm{~g}$ of E-octyl-MS3030 to add the same amount of enzymatic extract.

Regarding the catalytic results obtained over the biocatalytic systems, the E-octylMS3030 exhibited a higher conversion value in the transesterification reaction (89\%), in comparison to that obtained over the E-PMO (66.5\%). Considering the higher catalytic efficiency of the E-PMO in the pNPA and TB reaction tests, a higher conversion was expected for this biocatalyst, in comparison to the E-octyl-MS3030 but the opposite results were obtained. A possible explanation to this fact would reside in both the size of the reactant molecules, i.e., the high volume of triglyceride molecules together with the low pore size of E-PMO $(\sim 7 \mathrm{~nm}$, Table S1). Therefore, the active sites of the enzyme would be more accessible for the triglyceride molecules in the E-octyl-MS3030 (pore diameter around $28 \mathrm{~nm}$, Table S1) than in the E-PMO.

In addition to conversion values, Figure 2 also represents the viscosity values of the Ecodiesel obtained. As expected, the higher the conversion value, the lower the viscosity of the product. Figure 3 shows the evolution of conversion values with reaction time over the biocatalysts studied. In addition, reactions with supports at different reaction times $(1,4$ and $10 \mathrm{~h})$ have also been included.

The results obtained with supports stay constant at conversion values of $20-30 \%$, which are very similar to the value obtained with the blank reaction. Therefore, it can be confirmed that support did not catalyze the transesterification reaction. Regarding the conversion values obtained with the biocatalysts, the maximum conversion was reached at reaction times of 3-4 $\mathrm{h}$ and then, this stabilized, independent of the biocatalyst employed. The reaction time is an important parameter, when considering an industrial scale process, since it is essential to have biocatalysts capable of achieving high yields in the shortest reaction times. 


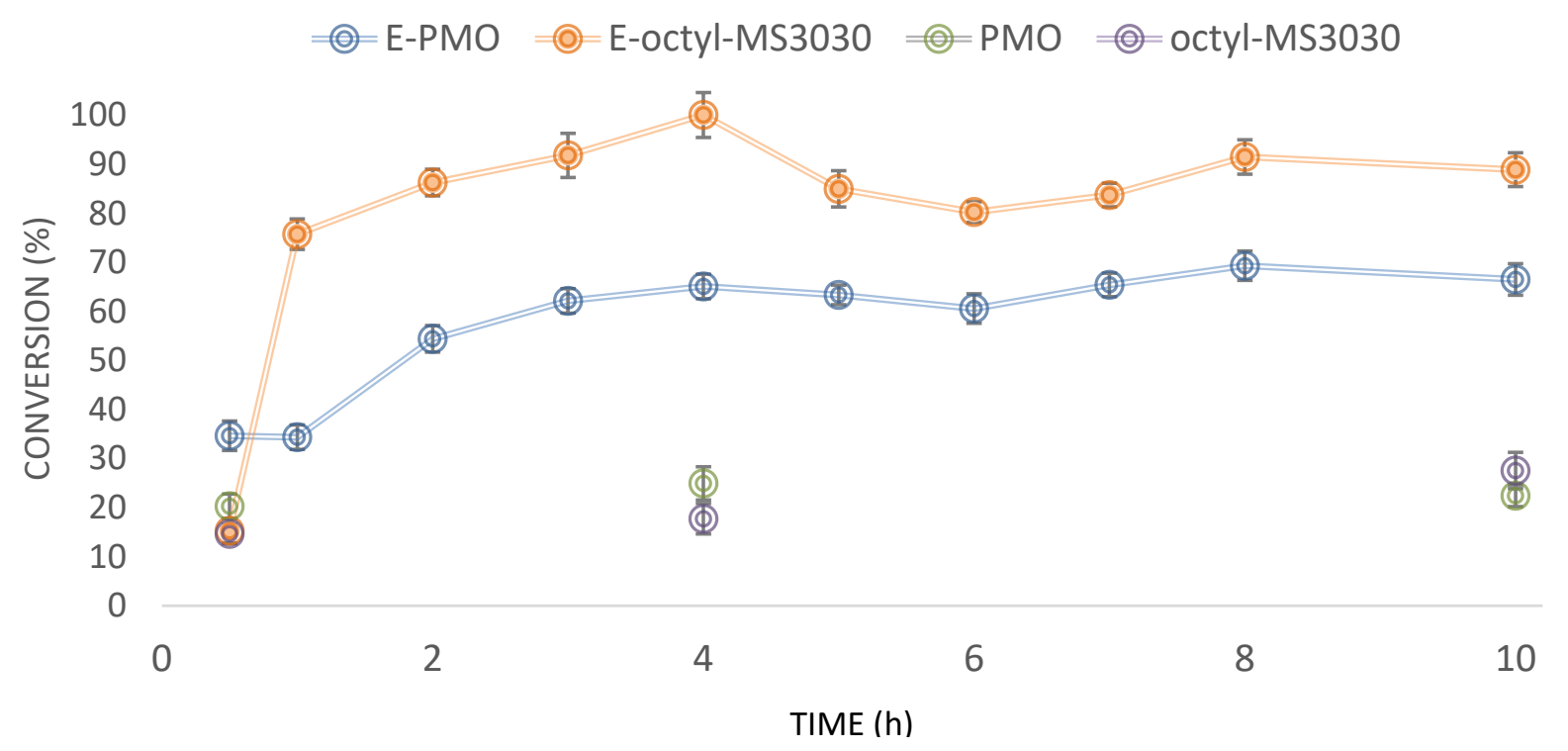

Figure 3. Study of the variation of conversion with time of reaction on the catalysts studied under the same experimental conditions as in Figure 2. Some conversion values obtained with the supports, without enzymatic load, have been also included.

Another essential parameter, for the possible application of a heterogeneous biocatalyst, is the possibility of its reuse in a high number of consecutive reaction cycles. The results obtained in the reuse tests of both biocatalysts are shown in Figure 4. It must be mentioned that no treatment was performed on the biocatalysts after each reaction.

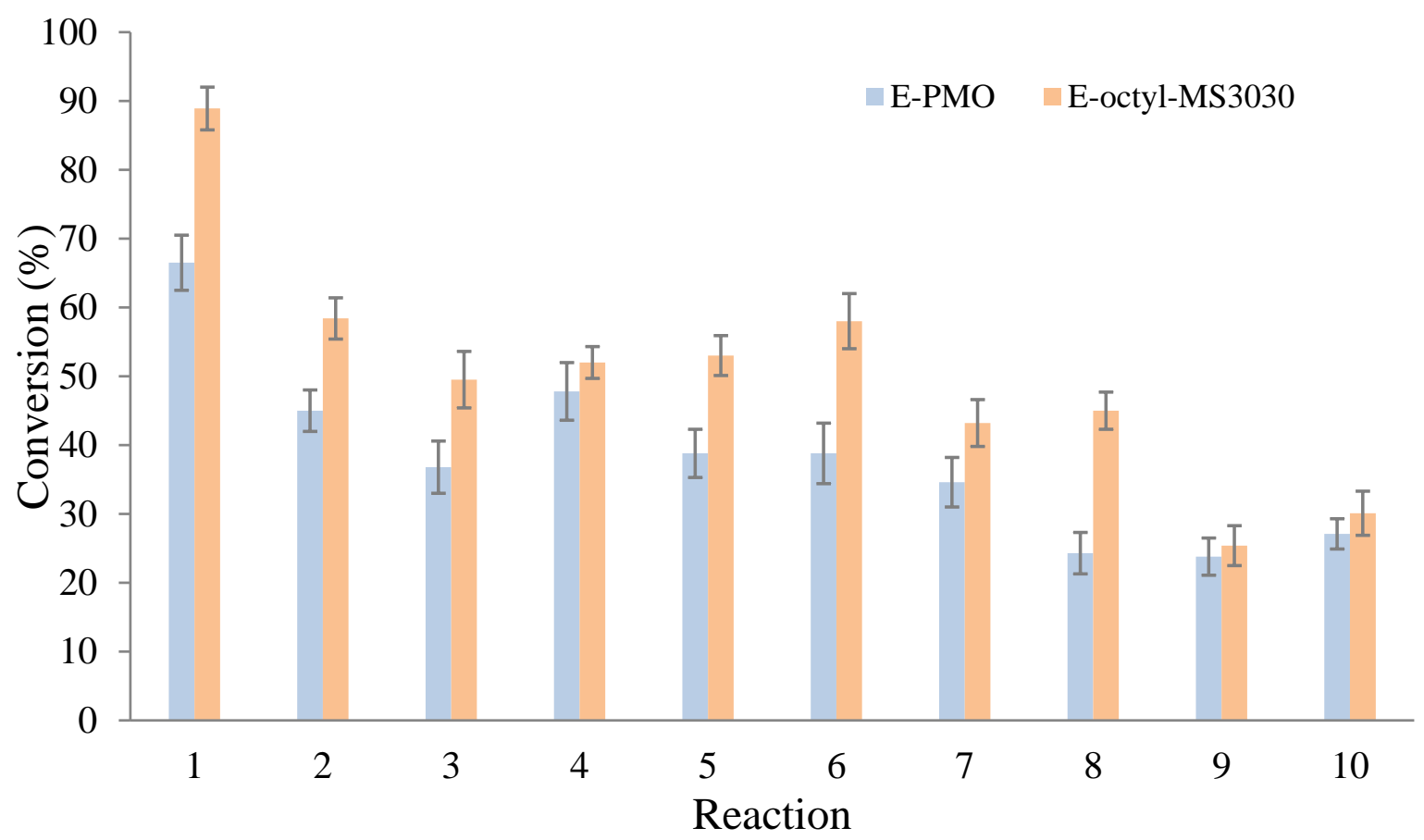

Figure 4. Influence of the catalyst recycling on the biocatalytic activity of E-PMO and E-octyl-MS3030 at $3 \mathrm{~h}$ of reaction time. Reaction conditions as in Figure 2.

Thus, the conversion felt around a 25-30\% after the first biocatalytic use and then, kept constant up to the 8th reuse. Finally, another decrease of around $20-25 \%$ was observed. Probably, the loss of activity after the 8th reuse could be related to the adsorption of some reactants to the support, mainly unreacted sunflower oil, making difficult the diffusion of 
the reactants to the active sites of the enzyme. Despite these activity losses, the possibility of performing a great number of reuses confirms the stability and efficiency of enzyme immobilization by physical adsorption on the PMO and octyl-MS3030 supports. In addition, considering that the cost of the commercial lipase is the limiting factor in the economic feasibility of the process (the price of commercial CALB is around 15 times higher than that of the support), its immobilization on the silica support in order to reuse it up to 10 times would represent a step forward for the possible industrial scaling up of the process.

\subsection{Comparison with Other Biocatalytic Systems Employed in the Ecodiesel Production}

The catalyst performance was compared with the activity of some of the reported immobilized enzymes in the selective transesterification of sunflower oil to produce Ecodiesel, Table 2.

Table 2. Reaction time, conversion values and viscosity of the biofuel obtained on the solids investigated herein and, on several catalysts previously reported by our research group.

\begin{tabular}{|c|c|c|c|c|c|}
\hline Enzyme & Support & $\begin{array}{c}\text { Reaction Time } \\
\text { (h) }\end{array}$ & $\begin{array}{c}\text { Conversion } \\
(\%)\end{array}$ & $\begin{array}{l}\text { Viscosity } \\
\quad(\mathrm{cSt})\end{array}$ & Reference \\
\hline CALB & PMO & 3 & 62.1 & 13.8 & This work \\
\hline CALB & octyl-MS3030 & 3 & 91.8 & 12.6 & This work \\
\hline PPL & Sepiolite & 24 & 65.1 & 16.6 & [8] \\
\hline PPL & $\mathrm{AlPO}_{4}$ & 24 & 49.1 & 16.6 & [9] \\
\hline PPL & $\mathrm{AlPO}_{4}$-Sepiolite & 24 & 58.7 & 12.9 & [10] \\
\hline ROL & Sepiolite & 2 & 84.0 & - & [12] \\
\hline Nov.435 & Acrylic resin & 24 & 57.9 & 12.3 & [11] \\
\hline LIP. RM IM & Sepiolite & 2 & 0 & 18.8 & [16] \\
\hline LIP. RM IM & Commercial silica & 2 & 83 & 11.6 & [16] \\
\hline
\end{tabular}

CALB: Candida antarctica lipase; PPL: porcine pancreatic lipase; ROL: Rhizopus oryzae lipase; LYP: lipozyme RM IM.

As can be seen, the E-PMO and E-octyl-MS3030 exhibited similar or even higher conversion value $(90 \%$ at $3 \mathrm{~h}$ and $100 \%$ at $4 \mathrm{~h}$ obtained over E-octyl-MS3030) than benchmark biocatalysts previously reported, the Rhizopus oryzae lipase (ROL) supported on sepiolite ( $84 \%$ of conversion) and the lypozime RM IM supported on amorphous silica (83\% of conversion), although the reaction time employed in the current research was slightly higher, $3 \mathrm{~h}$ vs. $2 \mathrm{~h}$ employed with ROL (Table 2). Therefore, the present results show the possibility of using this $C A L B$ commercial lipase, in immobilized form, to perform the ethanolysis of sunflower oil in a successful way, also considering the possibility of reusing it at least eight times without a dramatic loss of activity.

\section{Materials and Methods}

\subsection{Synthesis of the PMO Material}

PMO material used as inorganic support was synthesized following a previous reported procedure [28]. Briefly, in a Teflon bottle, $3.19 \mathrm{~g}$ of P123 were dissolved by slow stirring in $127 \mathrm{~mL}$ of $\mathrm{HCl}$ solution $0.174 \mathrm{M}$. Once the surfactant was dissolved, $9.38 \mathrm{~g}$ of $\mathrm{KCl}$ were added [29]. When homogenized, the solution was heated in a water bath to a constant temperature of $40{ }^{\circ} \mathrm{C}$. Then, $3.97 \mathrm{~mL}$ of the functional bis-alkoxysilane BTME was added dropwise and stirred vigorously. Then, stirring speed was diminished and the solution was kept at $40^{\circ} \mathrm{C}$ for $24 \mathrm{~h}$. Then, the solution was aged for another $24 \mathrm{~h}$ at $100{ }^{\circ} \mathrm{C}$ in the oven. The resulting product was filtered, washed with ethanol and dried at room temperature.

Surfactant was removed following a soft method that allows surfactant molecules to be removed without affecting the structure of organosiliceous materials [30]. We added $1.5 \mathrm{~g}$ of material, $205 \mathrm{~mL}$ of ethanol and $20 \mathrm{~mL}$ of concentrated $\mathrm{HCl}$ to a round bottom flask with a capacity of $500 \mathrm{~mL}$, keeping the mixture at reflux for $24 \mathrm{~h}$. A small amount of $\mathrm{HCl}$ was also added to improve the degree of condensation of the structure and minimize defects. The material was collected by vacuum filtration and washing with ethanol. The resulting powder was dried at room temperature for $24 \mathrm{~h}$. 


\subsection{Synthesis of Octyl-MS3030}

The functionalization of commercial MS3030 material was carried out by a grafting method [31], using octyl-triethoxysilane (OTES) as a silination agent, according to the scheme shown in Figure 5. Prior to silanization reaction, $5 \mathrm{~g}$ of the sample was degassed by subjecting it to a vacuum in a nitrogen stream at a temperature of $80^{\circ} \mathrm{C}$ for $20 \mathrm{~h}$ [23]. The grafting reaction was carried out by suspending the silica in $100 \mathrm{~mL}$ of dry toluene, the organic precursor (OTES) in excess ( $25 \mathrm{~g}$ ) was added to the dispersion, and kept at reflux with a stream of nitrogen for $48 \mathrm{~h}$ at $100{ }^{\circ} \mathrm{C}$. The solid was recovered by filtration, washed with dry toluene to remove the reagent in excess and then, with acetone to dry it. Finally, it was left to dry at room temperature for 1 day.

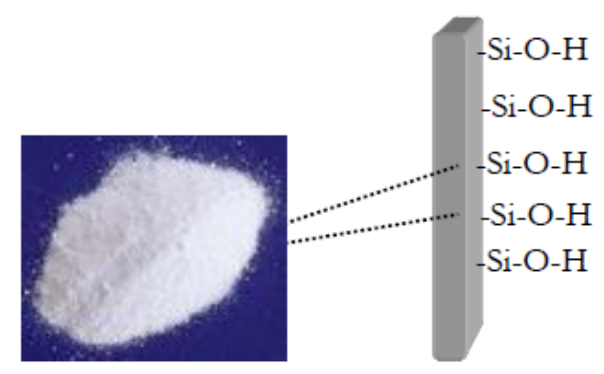

MS-3030

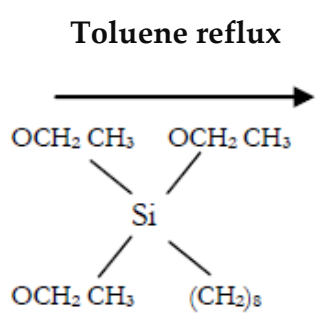

OTES

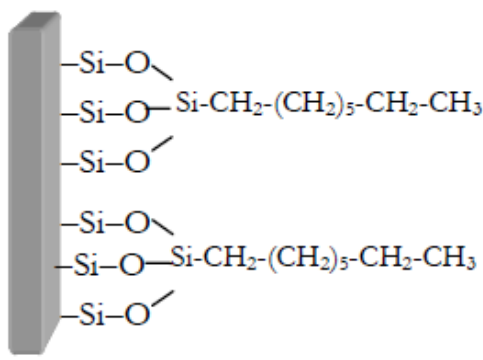

MS 3030-Octilo

Figure 5. Functionalization of commercial MS-3030 by anchoring an octyl group, through silanization reaction of the surface silanol groups, with the organosilane octyl-triethoxysilane, OTES.

\subsection{Immobilization of CALB Lipase on PMO and Octyl-MS3030}

Lipase immobilization was performed by physical adsorption at two different times ( 3.5 and $5.15 \mathrm{~h}$ ), following a reported procedure $[18,23]$. Table 3 shows the volume of ethanol required for every support, as well as the lipase extract and buffer volumes required to prepare the enzymatic solution at a fix $\mathrm{pH}$ of 5 , as it is the optimal $\mathrm{pH}$ value determined in previous studies [18]. In that research work, the buffer solutions used and their corresponding $\mathrm{pH}$ were: $50 \mathrm{mM}$ glycine/hydrochloric acid ( $\mathrm{pH} 3.5), 50 \mathrm{mM}$ sodium acetate/acetic acid ( $\mathrm{pH} 5.0), 50 \mathrm{mM}$ potassium dihydrogen phosphate/disodium hydrogen phosphate ( $\mathrm{pH} 7.0)$ and $50 \mathrm{mM}$ sodium carbonate/sodium bicarbonate ( $\mathrm{pH} 9.0)$.

Table 3. Required amounts to obtain the desired enzyme load (400 mg lipase/g support) in both supports, PMO or octyl-MS3030.

\begin{tabular}{ccccccc}
\hline Support & $\mathbf{m}_{\text {support }}(\mathbf{m g})$ & Ethanol $(\mathbf{m L})$ & $\begin{array}{c}\text { Enzymatic Extract } \\
(\mathbf{m g} / \mathbf{m L})\end{array}$ & $\begin{array}{c}\text { Enzymatic } \\
\text { Extract }(\mathbf{m L})\end{array}$ & $\begin{array}{c}\text { Buffer } \\
(50 \mathrm{mM}, \mathrm{pH} \text { 5.0) }\end{array}$ & $\begin{array}{c}\text { Enzymatic } \\
\text { Solution }(\mathrm{mL})\end{array}$ \\
\hline $\begin{array}{c}\text { PMO/ } \\
\text { Octyl-MS3030 }\end{array}$ & 500 & 2,5 & 5,9 & 139 & 66 & 205 \\
\hline
\end{tabular}

We weighed $500 \mathrm{mg}$ of either PMO or octyl-MS3030 into a plastic bottle, moistened with dry ethanol (maintaining the ratio of $0.5 \mathrm{~mL}$ of ethanol/100 $\mathrm{mg}$ of solid) and capped it. Then, a fixed volume of enzyme solution was prepared, considering the necessary volume of commercial lipase extract to achieve the enzymatic load, Table 3. In addition, a blank solution was obtained by taking a few milliliters of the enzyme solution, and measuring its activity three times. The fixed volume of the enzyme solution was suspended on the support. The resulting suspension was capped and kept under stirring on a roller agitator, at low speed to avoid breakage of the material. 


\subsection{Lipase Activity Assay towards the pNPA Hydrolysis}

This assay allows the measurement of non-specific esterase activity, and is often employed as a standard method to assess the degree of immobilization of lipase on a support [18]. Lipase activity was determined by spectrophotometric analysis of $\mathrm{p}$ nitrophenylacetate (pNPA) hydrolysis on an Agilent $8453 \mathrm{UV}-\mathrm{Vis}$ spectrophotometer at $348 \mathrm{~nm}$ and using $1 \mathrm{~cm}$ optical path cuvettes. The immobilization concludes this process as the activity of the supernatant is totally lost. At this point, the suspension was then filtered under vacuum, washed with $200 \mathrm{mM}$ buffer $\mathrm{pH} 5.0$ and dried with acetone. Once the biocatalyst obtained was dry, it was collected and stored in the refrigerator to avoid loss of activity. For each test, aliquots of the blank, the suspension and the supernatant were taken periodically to check the incorporation of the enzyme to the support. Taking into account that an enzyme unit, $\mathrm{U}$, is defined as the amount of enzyme that transforms one $\mu \mathrm{mol}$ of substrate per minute, this value can be transform into enzyme activity units using Equation (1).

$$
A_{\mathcal{e}}(\mathrm{U} / \mathrm{mL})=\frac{\Delta A \cdot V_{T} \cdot 1000 \cdot d}{\varepsilon \cdot L \cdot V_{M}}
$$

where $A_{\mathrm{e}}$ is the enzymatic activity $(\mathrm{U} / \mathrm{mL}), \Delta A$ is the increase in absorbance per minute $(\triangle A b s / \mathrm{min}), V_{T}$ refers to the total volume in $\mathrm{mL}$ added to the cuvette $(1.90 \mathrm{~mL}+0.05 \mathrm{~mL})$, $d$ is the dilution, $\varepsilon$ is the molar extinction coefficient (at $25^{\circ} \mathrm{C}, \varepsilon \varepsilon^{348 \mathrm{~nm}}=5.150 \mathrm{M}^{-1} \mathrm{~cm}^{-1}$ ), $L$ is the light path length $(1 \mathrm{~cm}), V_{M}$, refers to the volume of the aliquot of blank sample, suspension or supernatant added to the cuvette $(0.05 \mathrm{~mL})$. Tests were undertaken in triplicate and the results are shown as average along with standard deviation, represented as error bars.

From the enzyme concentration in the enzyme solution, $\mathrm{Ce}(\mathrm{mg} / \mathrm{mL})$, the specific activity is calculated in $\mathrm{U} / \mathrm{mg}$, by using Equation (2).

$$
A_{e}(\mathrm{U} / \mathrm{mg})=\frac{\Delta A \cdot V_{T} \cdot 1000 \cdot d}{\varepsilon \cdot L \cdot V_{M} \cdot C_{e}}
$$

\subsection{Lipase Activity Assay towards the Tributyrin Hydrolysis}

The hydrolysis of tributyrin has also been used as a more specific test to determine the catalytic activity, based on the release of butyric acid generated by the hydrolitic action of lipases in the tributyrin molecules, according to Figure 6.
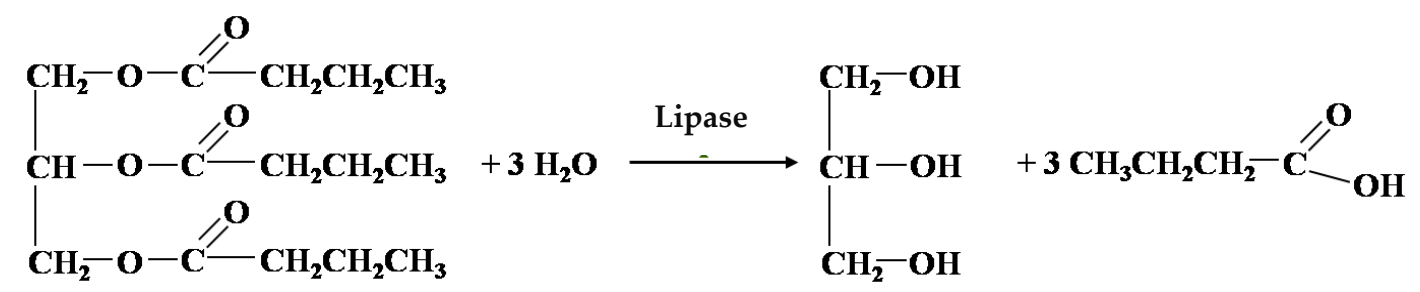

Figure 6. Enzymatic hydrolysis reaction of tributyrin, which generates one molecule of glycerin and three of butyric acid.

This reaction was carried out in a weakly buffered solution constantly at $\mathrm{pH}$ 7.0, using a Mettler Toledo DL-50 $\mathrm{pH}$-stat. Thus, as the reaction occurs releasing butyric acid, the equipment released the volume of $\mathrm{NaOH} 100 \mathrm{mM}$ necessary to maintain the $\mathrm{pH}$ at constant value [18]. Thus, $48.5 \mathrm{~mL}$ of $10 \mathrm{mM}$ potassium phosphate buffer $\mathrm{pH} 7.0$ and $1.47 \mathrm{~mL}$ of tributyrin were poured into a beaker with stirring. A known biocatalyst mass, $m_{B}$, was then introduced in the beaker. The addition rate of sodium hydroxide, $v_{\mathrm{NaOH}}$, which was necessary to maintain a constant $7.0 \mathrm{pH}$ value, obtained the slope value of the line that corresponded to the rate of hydrolysis, and therefore, the activity of the enzyme. Thus, the tributyrin units $\left(U_{T B}\right)$ are obtained from Equation (3):

$$
U_{T B}\left(\mathrm{U}_{\mathrm{TB}} / \mathrm{g}\right)=\frac{v_{\mathrm{NaOH}}(\mathrm{mL} / \mathrm{min}) \cdot 100(\mu \mathrm{mol} / \mathrm{mL})}{m_{B}(\mathrm{~g})}
$$


In this respect, the catalytic efficiency of an immobilized lipase biocatalyst is defined as the activity/load ratio, according to Equation (4):

$$
A_{e}\left(U_{T B} / m g \text { lipase }\right)=\frac{U_{T B} / g \text { catalyst }}{\text { immobilized enzyme }(m g \text { lipase } / g \text { support })}
$$

Following these steps, the enzyme loading and catalytic activity values of the biocatalytic systems prepared and shown in Table 1 were calculated. Tests were undertaken in triplicate and the results are shown as averages along with standard deviation, represented as error bars.

\subsection{Ethanolysis Reaction \\ 3.6.1. Chemicals}

Commercial sunflower oil was locally obtained. The chromatographically pure ethyl esters of palmitic acid, stearic acid, oleic acid, linoleic acid, and linolenic acid were commercially obtained from AccuStandard (New Haven, CT, USA), and hexadecane (cetane) was obtained from SigmaAldrich (St. Louis, MO, USA). Other chemicals like absolute ethanol and sodium hydroxide were pure analytical compounds (99.5\%) obtained commercially from Panreac (Castellar Del Valles, Spain)

\subsubsection{Transesterification of Sunflower Oil with Ethanol to Produce Ecodiesel}

The selective enzymatic transesterification reactions were carried out in a stirred tank reactor ("Batch") at atmospheric pressure at the reaction conditions previously reported by our Research Group [15,16]. This allowed the comparison of the results among the biocatalysts, and especially with the CALB lipases $[11,15]$. Briefly, the same enzymatic charge, $0.1 \mathrm{~g}$ of E-PMO or $0.05 \mathrm{~g}$ of CALB/MS-3030, was added to a $25 \mathrm{~mL}$ two-necked round bottom flask and the temperature was fixed at $30^{\circ} \mathrm{C}$ with the help of a thermostatic bath. Then, $6 \mathrm{~mL}$ of commercial sunflower oil $(4.7 \mathrm{~g}, 0.005 \mathrm{~mol}), 1.75 \mathrm{~mL}$ of absolute ethanol, and $25 \mu \mathrm{L}$ of $10 \mathrm{~N} \mathrm{NaOH}$ were added and stirred at $300 \mathrm{rpm}$.

A blank experiment was performed, giving a conversion value inferior to $10 \%$. All experiments were repeated a minimum of three times and the standard deviation was always lower than $6 \%$. The reuse experiments were performed with the two supported systems investigated, operating under the same standard experimental conditions. To do this, the mixture was decanted for $1 \mathrm{~h}$ and then the reaction products were extracted, leaving the biocatalyst at the bottom of the batch reactor. Afterwards, the reagents were added to generate a new reaction cycle. Tests were undertaken in triplicate and the results are shown as an average along with standard deviation, represented as error bars.

\subsubsection{Analytical Method}

Determination of the content of methyl esters, ethyl esters and different glycerides in the biofuel samples was carried out by a chromatographic method developed in previous research $[32,33]$. Thus, an HP 5890 Series II gas chromatograph with a HT5 (25 m $\times 0.32 \mathrm{~mm}$ I.D $\times 0.1 \mu \mathrm{m}$, SGE, Supelco) Aldrich Chemie capillary column and equipped with a flame ionization detector (FID) was employed. Cetane (n-hexadecane) was used as an internal standard.

Results obtained are expressed as the relative amounts of the corresponding methyl esters (FAME, fatty acid methyl esters), monoglycerides (MG), and diglycerides (DG). The amount of diglycerides (DG) and triglycerides (TG) which had not reacted was calculated from the difference to the internal standard (cetane). Thus, the conversion included the total amount of triglyceride transformed (FAEE + MG + DG) in the methanolysis process, and selectivity referred to the relative amount of FAEE + MG obtained.

\subsection{Viscosity Measurements}

Kinematic viscosity was determined following the methodology described in previous works $[34,35]$, according to specifications established by the European standard 
(EN 590 ISO 3104). Thus, kinematic viscosity was measured in an Ostwald-Cannon-Fenske capillary viscometer (Proton Routine Viscometer 33,200, size 150) working at $40{ }^{\circ} \mathrm{C}$. The kinematic viscosity $(v)$, expressed in centistokes (cSt) or $\mathrm{mm}^{2} / \mathrm{s}$, was calculated from Equation (5):

$$
v=C \cdot t
$$

where $t$ is the flow time in seconds, required for a certain volume of liquid to pass under gravity between two marked points on the instrument, and $C$ is the calibration constant of the measurement system, supplied by the manufacturer $\left(0.037150\left(\mathrm{~mm}^{2} / \mathrm{s}\right) / \mathrm{s}\right.$ at $\left.40{ }^{\circ} \mathrm{C}\right)$. All the viscosities values reported here are the media of three determinations. The error is indicated as standard deviation.

\section{Conclusions}

E-PMO and E-octyl-MS3030 were obtained by physical immobilization of the commercial CALB lipase (E) on periodic mesoporous organosilica (PMO) and on octyl-functionalized commercial silica (MS-3030). The effectiveness in the immobilization process was measured by two lipase activity tests, the hydrolysis of p-NPA and the hydrolysis of tributyrin. The biocatalytic efficiency of E-PMO was superior to that exhibited by E-octyl-MS3030. However, the E-octyl-MS3030 exhibited a higher catalytic activity in the selective transesterification of sunflower oil with ethanol to produce biodiesel. These differences were ascribed to the textural properties of the supports. The octyl-MS3030, with a higher size of pores would allow a better diffusion of the reactant to the active sites of the enzyme.

In addition, the biocatalysts reported here were subjected up to 10 reuses, showing a decrease in activity after the first use and also after the eighth reuse. This fact will contribute to the economic feasibility of the process, since the price of commercial lipase is the limiting factor for scaling up.

In summary, we can conclude that the results obtained in this research indicate that a commercial CALB lipase, immobilized on inorganic supports, is viable and effective in obtaining selective 1,3 ethanolysis processes, where glycerol remains as MG in the biofuel mixture, with different FAEEs obtained and together with the excess of unreacted ethanol. Thus, a new type of biofuel is achieved, called Ecodiesel, consisting of a mixture of monoacylglycerols and FAEEs mainly (nominally 1/2), which can be used in different mixtures with diesel fuel, in a similar way to how the biodiesel (made up exclusively of mixtures of FAEEs or FAMEs) is employed in current internal combustion engines, which operate with fossil diesel.

Supplementary Materials: The following are available online at https:/ / www.mdpi.com/article / 10.3390 / catal11111350/s1, Table S1: Textural properties of the supports employed for the enzyme immobilization.

Author Contributions: This research article is part of the doctoral thesis of C.L., directed by professors D.L., F.M.B. and C.V.-E., who in a general way conceived and designed the experiments and wrote the paper. V.G.-P. collaborated in a decisive way contributing everything concerning the investigated inorganic supports. R.E., F.J.L.-T., J.C. and L.A.-D. have made also substantive intellectual contributions to this study, substantial input to conception and design, as well as to the acquisition, analysis and interpretation of data. A.A.R. and R.E. were also involved in drafting and revising the manuscript, so that everyone gave final approval to the current version to be published in Catalysts journal. All authors have read and agreed to the published version of the manuscript.

Funding: This research received no external funding.

Acknowledgments: This research is supported by MINECO-ENE2016-81013-R (AEI/FEDER, EU), MICIIN (Project ref. PID2019-104953RB-100), Consejería de Transformación Económica, Industria, Conocimiento y Universidades de la Junta de Andalucía (UCO-FEDER Project CATOLIVAL, ref. 1264113-R, 2018, and Project ref. P18-RT-4822) and FEDER Funds for financial support. The Government of Ireland Postdoctoral Fellowship Programme-2015 (GOIPD/2015/287) is thankfully acknowledge by V.G.-P. 
Conflicts of Interest: The authors declare no conflict of interest.

\section{References}

1. Gray, N.; McDonagh, S.; O'Shea, R.; Smyth, B.; Murphy, J.D. Decarbonising ships, planes and trucks: An analysis of suitable low-carbon fuels for the maritime, aviation and haulage sectors. Adv. Appl. Energy 2021, 1, 100008. [CrossRef]

2. Ortar, N.; Ryghaug, M. Should all cars be electric by 2025? The electric car debate in Europe. Sustainability 2019, 11, 1868. [CrossRef]

3. Darda, S.; Papalas, T.; Zabaniotou, A. Biofuels journey in Europe: Currently the way to low carbon economy sustainability is still a challenge. J. Clean. Prod. 2019, 208, 575-588. [CrossRef]

4. Arutyunov, V.S.; Lisichkin, G.V. Energy resources of the 21st century: Problems and forecasts. Can renewable energy sources replace fossil fuels? Russ. Chem. Rev. 2017, 86, 777. [CrossRef]

5. Zailani, S.; Iranmanesh, M.; Foroughi, B.; Kim, K.; Hyun, S.S. Effects of supply chain practices, integration and closed-loop supply chain activities on cost-containment of biodiesel. Rev. Manag. Sci. 2020, 14, 1299-1319. [CrossRef]

6. Estevez, R.; Aguado-Deblas, L.; Bautista, F.M.; Luna, D.; Luna, C.; Calero, J.; Posadillo, A.; Romero, A.A. Biodiesel at the Crossroads: A Critical Review. Catalysts 2019, 9, 1033. [CrossRef]

7. Calero, J.; Luna, D.; Sancho, E.D.; Luna, C.; Bautista, F.M.; Romero, A.A.; Posadillo, A.; Berbel, J.; Verdugo-Escamilla, C. An overview on glycerol-free processes for the production of renewable liquid biofuels, applicable in diesel engines. Renew. Sustain. Energy Rev. 2015, 42, 1437-1452. [CrossRef]

8. Caballero, V.; Bautista, F.M.; Campelo, J.M.; Luna, D.; Marinas, J.M.; Romero, A.A.; Hidalgo, J.M.; Luque, R.; Macario, A.; Giordano, G. Sustainable preparation of a novel glycerol-free biofuel by using pig pancreatic lipase: Partial 1, 3-regiospecific alcoholysis of sunflower oil. Process Biochem. 2009, 44, 334-342. [CrossRef]

9. Luna, D.; Posadillo, A.; Caballero, V.; Verdugo, C.; Bautista, F.M.; Romero, A.A.; Sancho, E.D.; Luna, C.; Calero, J. New biofuel integrating glycerol into its composition through the use of covalent immobilized pig pancreatic lipase. Int. J. Mol. Sci. 2012, 13, 10091-10112. [CrossRef]

10. Luna, C.; Sancho, E.; Luna, D.; Caballero, V.; Calero, J.; Posadillo, A.; Verdugo, C.; Bautista, F.M.; Romero, A.A. Biofuel that keeps glycerol as monoglyceride by 1,3-selective ethanolysis with pig pancreatic lipase covalently immobilized on $\mathrm{AlPO}_{4}$ support. Energies 2013, 6, 3879-3900. [CrossRef]

11. Luna, C.; Verdugo, C.; Sancho, E.D.; Luna, D.; Calero, J.; Posadillo, A.; Bautista, F.M.; Romero, A.A. Production of a biodiesel-like biofuel without glycerol generation, by using Novozym 435, an immobilized Candida antarctica lipase. Bioresour. Bioprocess. 2014, 1, 11. [CrossRef]

12. Luna, C.; Verdugo, C.; Sancho, E.D.; Luna, D.; Calero, J.; Posadillo, A.; Bautista, F.M.; Romero, A.A. Biocatalytic behaviour of immobilized Rhizopus oryzae lipase in the 1,3-selective ethanolysis of sunflower oil to obtain a biofuel similar to biodiesel. Molecules 2014, 19, 11419-11439. [CrossRef] [PubMed]

13. Calero, J.; Verdugo, C.; Luna, D.; Sancho, E.D.; Luna, C.; Posadillo, A.; Bautista, F.M.; Romero, A.A. Selective ethanolysis of sunflower oil with Lipozyme RM IM, an immobilized Rhizomucor miehei lipase, to obtain a biodiesel-like biofuel, which avoids glycerol production through the monoglyceride formation. New Biotechnol. 2014, 31, 596-601. [CrossRef] [PubMed]

14. Luna, C.; Verdugo, C.; Sancho, E.D.; Luna, D.; Calero, J.; Posadillo, A.; Bautista, F.M.; Romero, A.A. A biofuel similar to biodiesel obtained by using a lipase from Rhizopus oryzae, optimized by response surface methodology. Energies 2014, 7, 3383-3399. [CrossRef]

15. Luna, C.; Luna, D.; Bautista, F.M.; Estevez, R.; Calero, J.; Posadillo, A.; Romero, A.A.; Sancho, E.D. Application of Enzymatic Extracts from a CALB Standard Strain as Biocatalyst within the Context of Conventional Biodiesel Production Optimization. Molecules 2017, 22, 2025. [CrossRef] [PubMed]

16. Calero, J.; Luna, D.; Luna, C.; Bautista, F.M.; Hurtado, B.; Romero, A.A.; Posadillo, A.; Estevez, R. Rhizomucor miehei Lipase Supported on Inorganic Solids, as Biocatalyst for the Synthesis of Biofuels: Improving the Experimental Conditions by Response Surface Methodology. Energies 2019, 12, 831. [CrossRef]

17. Serra, E.; Díez, E.; Díaz, I.; Blanco, R.M. A comparative study of periodic mesoporous organosilica and different hydrophobic mesoporous silicas for lipase immobilization. Microporous Mesoporous Mater. 2010, 132, 487-493. [CrossRef]

18. Gascón, V.; Díaz, I.; Blanco, R.; Márquez-Álvarez, C. Hybrid periodic mesoporous organosilica designed to improve the properties of immobilized enzymes. RSC Adv. 2014, 4, 34356-34368. [CrossRef]

19. Rodrigues, R.C.; Virgen-Ortíz, J.J.; Dos Santos, J.C.; Berenguer-Murcia, Á.; Alcantara, A.R.; Barbosa, O.; Ortiz, C.; FernandezLafuente, R. Immobilization of lipases on hydrophobic supports: Immobilization mechanism, advantages, problems, and solutions. Biotechnol. Adv. 2019, 37, 746-770. [CrossRef] [PubMed]

20. Costantini, A.; Califano, V. Lipase Immobilization in Mesoporous Silica Nanoparticles for Biofuel Production. Catalysts 2021, 11, 629. [CrossRef]

21. Kim, K.; Lee, O.; Lee, E. Nano-immobilized biocatalysts for biodiesel production from renewable and sustainable resources. Catalysts 2018, 8, 68. [CrossRef]

22. Guisan, J.M.; Bolivar, J.M.; López-Gallego, F.; Rocha-Martín, J. Immobilization of Enzymes and Cells: Methods and Protocols; Springer: Berlin/Heidelberg, Germany, 2020. 
23. Blanco, R.M.; Terreros, P.; Fernández-Pérez, M.; Otero, C.; Díaz-González, G. Functionalization of mesoporous silica for lipase immobilization: Characterization of the support and the catalysts. J. Mol. Catal. B Enzym. 2004, 30, 83-93. [CrossRef]

24. Gascón-Pérez, V.; Jiménez, M.B.; Molina, A.; Blanco, R.M.; Sánchez-Sánchez, M. Efficient One-Step Immobilization of CaLB Lipase over MOF Support NH2-MIL-53 (Al). Catalysts 2020, 10, 918. [CrossRef]

25. Venezia, V.; Sannino, F.; Costantini, A.; Silvestri, B.; Cimino, S.; Califano, V. Mesoporous silica nanoparticles for $\beta$-glucosidase immobilization by templating with a green material: Tannic acid. Microporous Mesoporous Mater. 2020, 302, 110203. [CrossRef]

26. Catalano, F.; Alberto, G.; Ivanchenko, P.; Dovbeshko, G.; Martra, G. Effect of silica surface properties on the formation of multilayer or submonolayer protein hard corona: Albumin adsorption on pyrolytic and colloidal SiO2 nanoparticles. J. Phys. Chem. C 2015, 119, 26493-26505. [CrossRef]

27. Venerando, R.; Miotto, G.; Magro, M.; Dallan, M.; Baratella, D.; Bonaiuto, E.; Zboril, R.; Vianello, F. Magnetic nanoparticles with covalently bound self-assembled protein corona for advanced biomedical applications. J. Phys. Chem. C 2013, 117, 20320-20331. [CrossRef]

28. Qiao, S.; Yu, C.; Hu, Q.; Jin, Y.; Zhou, X.; Zhao, X.; Lu, G. Control of ordered structure and morphology of large-pore periodic mesoporous organosilicas by inorganic salt. Microporous Mesoporous Mater. 2006, 91, 59-69. [CrossRef]

29. Guo, W.; Park, J.-Y.; Oh, M.-O.; Jeong, H.-W.; Cho, W.-J.; Kim, I.; Ha, C.-S. Triblock copolymer synthesis of highly ordered large-pore periodic mesoporous organosilicas with the aid of inorganic salts. Chem. Mater. 2003, 15, 2295-2298. [CrossRef]

30. Wan, Y.; Zhao, D. On the controllable soft-templating approach to mesoporous silicates. Chem. Rev. 2007, 107, 2821-2860. [CrossRef]

31. Feng, X.; Fryxell, G.E.; Wang, L.-Q.; Kim, A.Y.; Liu, J.; Kemner, K.M. Functionalized monolayers on ordered mesoporous supports. Science 1997, 276, 923-926. [CrossRef]

32. Verdugo, C.; Luque, R.; Luna, D.; Hidalgo, J.M.; Posadillo, A.; Sancho, E.D.; Rodriguez, S.; Ferreira-Dias, S.; Bautista, F.; Romero, A.A. A comprehensive study of reaction parameters in the enzymatic production of novel biofuels integrating glycerol into their composition. Bioresour. Technol. 2010, 101, 6657-6662. [CrossRef] [PubMed]

33. Hurtado, B.; Posadillo, A.; Luna, D.; Bautista, F.; Hidalgo, J.; Luna, C.; Calero, J.; Romero, A.; Estevez, R. Synthesis, Performance and Emission Quality Assessment of Ecodiesel from Castor Oil in Diesel/Biofuel/Alcohol Triple Blends in a Diesel Engine. Catalysts 2019, 9, 40. [CrossRef]

34. Estevez, R.; Aguado-Deblas, L.; Posadillo, A.; Hurtado, B.; Bautista, F.M.; Hidalgo, J.M.; Luna, C.; Calero, J.; Romero, A.A.; Luna, D. Performance and Emission Quality Assessment in a Diesel Engine of Straight Castor and Sunflower Vegetable Oils, in Diesel/Gasoline/Oil Triple Blends. Energies 2019, 12, 2181. [CrossRef]

35. Aguado-Deblas, L.; Hidalgo-Carrillo, J.; Bautista, F.M.; Luna, D.; Luna, C.; Calero, J.; Posadillo, A.; Romero, A.A.; Estevez, R. Diethyl ether as an oxygenated additive for fossil diesel/vegetable oil blends: Evaluation of performance and emission quality of triple blends on a diesel engine. Energies 2020, 13, 1542. [CrossRef] 